\title{
"RENVOI" IN THE SUCCESSION TO TANGIBLES: A FALSE ISSUE BASED ON FAULTY ANALYSIS*
}

\author{
EDWIIN W. BRIGGS $\dot{\dagger}$
}

THE so-called renvoi problem arises whenever a court refers to a foreign law to determine legal rights: should it practice renvoi and refer to the "whole" law of the foreign state, including its conflicts rules, or should it only apply the internal law of that state? A growing body of decisions and scholars approve the renvoi in one or another form. ${ }^{1}$ The version most consistently found in recent English cases, and winning greatest favor among the writers, is this: When the forum, $F$, refers to the law of a second state, $S,{ }^{3}$ it should sit and judge as would the $S$ court in this precise litigation.* Still, determined and responsible commentators condemn any form of renvoi: "Its days ought to be few after its deceptive character is fully understood." The clashing views of equally competent authorities suggest that there is some truth and some error in both camps.

The thesis of this article is this: At least in the field of interests in tangible property, the dispute over the renvoi stems from a failure to recognize that there are two kinds of conflicts rules, at two policy levels, by which a court refers to foreign law. At the highest policy level is the "jurisdictional rule" under which the forum recognizes the exclusive legislative power of the situs

*Though condensed and retitled, this is the "In Re Duke of Wellinglon" paper referred to in Briggs, Utility of the Jurisdictional Principle in a Policy Centered Confict of Lawes, 6 VAND. L. REv. 667 (1953).

$\doteqdot$ Professor of Law, Montana State University.

1. See, e.g., Bentwish, The Law of Donicrle in its Retation to Successio: 179 (1911) ; Dicey, The Conflict of Laws 77 (1st ed. 1896); Id. at 70 (4th ed., Keith, 1927); Wolff, Private Internattonal Law 186 et seq. (2d ed. 1950); Griswold, Renedi Revisited, 51 HARv. L. REv. 1165 (1938). Although formerly strongly opposed, Couk: approves renvoi in some circumstances. CoOK, THE LoGicil AND LEg.lL. Basfs of THE Conflict of Laws 245 et seq. (1942). Also fully approving in special cases, is Falconbridge, Confict of Laws: 1923-1947, 26 CAN. BAR. Rev. 334, 342 (1943), though he continues to oppose generally.

2. 1 Rabel, The Conflict of Laws, A Codrparative Study 76 al seq. (1945), warmly approves the "English rule" of renvoi. See also Griswold, supra note 1, and Falconbridge, supra note 1 .

3. Hereafter, the forum will be described as ' $F$ ' ' the second state to which the forum refers as ' $S$,' and a third state to which $S$ refers as ' $T$.'

4. Presumably this was first clearly formulated in Collier v. Rivaz, 2 Curt. 855, 163 Eng. Rep. 608 (Ecc. 1S41).

5. Lorenzen, The Renvoi Doctrine in the Confict of Laws-II saning of "The Law of a Country," 27 Yale L.J. 509, 529 (1918). For further criticism see Morris, Renuvi, 64 L.Q. Rev. 264 (1948) ; MIann, Succession to Immorables Abrood, 11 Mfov. L. KEv. 232 (1948); Mendelssohn-Bartholdy, Renvor in Modera Exalusn L.iW (Cheshire ed. 1937); Cheshire, Private International Law 85 et seq. (3d ed. 1947); Sturomerg, CoNflict of Laws 11n.28, 203 (1937). But cf. id. at 11n.2s (2d. ed. 1951). 
to delimit interests in tangibles. At the secondary level is the "choice of law" rule by which the situs refers to the law of a foreign state to effectuate its own particular policies regarding the matter litigated. ${ }^{6}$ Thus there are entirely different considerations causing a non-situs forum and a situs forum to refer to foreign law. When the non-situs forum refers to the law of the situs it recognizes the legislative power of the situs, and seeks to delimit interests in the property precisely as would the situs. In this case $F$ properly may sit and judge as an $S$ court. ${ }^{7}$ But the situs forum has legislative power, and when it refers to a foreign law it does so only to effectuate some policy of its own-e.g., to insure "unitary" succession to an estate under the law of the domicil. The situs ordinarily should not sit and judge as the foreign court, but should refer directly to $S$ 's internal law. Traditional tests for when renvoi should be practiced-"social"8 or "practical" "convenience," or "justice in the particular case"10_fail to distinguish the basically different reasons for which situs and non-situs refer to foreign law.

Neither the position of the anti-renvoists, that a reference to foreign law should never include conflicts rules, nor that of the renvoists, that it should always include conflicts rules, is valid. A single rule, rejecting or favoring renvoi, cannot be framed for both situs and non-situs; it can not consider the governmental relationship of the forum to the property, nor the policy reasons actually present for referring to foreign law. The anti-renvoists' argument appears to be a generalization of the point of view of the situs court, and the renvoists' argument a generalization of that of a non-situs court.

In those fields where the jurisdictional and choice of law rules exist, they are presently lumped together under the "choice of law" label, and the confusion is confounded by the assumption that the forum is always free to use its own choice of law rule. If the choice of law rules were separated from and subordinated to the jurisdictional rules, the only choice of law rule available to the forum would be that of the state with the governmental power, i.e., the situs. ${ }^{11}$ In exercising its jurisdictional rule, a non-situs forum would

6. For development of the jurisdictional-choice-of-law dichotomy, see Briggs, The Jurisdictional-Choice-of-Laze Relation in Conflicts Rules, 61 HARv. L. REv. 1165 (1948); Briggs, Utility of the Jurisdictional Principle in a Policy Centered Conflict of Lazes, 6 VAND. L. REv. 667 (1953).

7. Strictly speaking, $F$ does not sit and judge exactly as a court at the situs: $F^{\prime}$ s reference should include only $S$ s choice of law rules, not its jurisdictional rules. As a practical matter, in the field of succession to tangibles a reference including both kinds of conflicts rules will result in no error, for the jurisdictional rules of all states refer to the situs-F's and $S$ 's jurisdictional rules agree.

8. See Cook, The Logical and Legal Bases of the Conflict of Laws 65, 252-3 (1942).

9. See Goodrich, Two States and Real Estate, 89 U. of PA. L. Rev. 417, 418 (1941).

10. See Lorenzen, Territoriality, Public Policy and the Confict of Lazes, 33 YALE L.J. 736, 748 (1924); Graveson, The Conflict of Laws 55 (1948).

11. For a diagrammatic analysis of the renvoi problem in terms of the two kinds of conflicts rules, see Briggs, Utility of the Jurisdictional Principle in a Policy Centered Confict of Lawes, 6 VAND. L. REv. 667, 669, 697-700 (1953). 
be led to the whole law of the situs. It would never apply its own choice of law rule because, by virtue of its jurisdictional rule, it has no choice of law rule for tangibles situated in another state. ${ }^{12}$ The result is that all other courts would be guided by what the situs court would do with the particular property, and not by what some other court, such as the domiciliary or national court, would do with hypothetical property.

\section{Situs: Jurisdictional Rule for Land and Chattels}

The best example of the jurisdictional-choice-of-law dichotomy, and the two policy levels at which reference is made to foreign law, is found in the field of interests in land. ${ }^{13}$ Here all legal systems have formulated the same conflicts rule: the law of the situs delimits legal interests in land. When a non-situs state, in a case involving real property, refers to the situs' law, it does so for the purpose of creating a right as nearly like that which the situs would create as is practicable, in order to insure recognition at the situs of the interest declared. ${ }^{14}$ Consequently, when a state merely as the form refers to the law of the situs, there is every good reason for it to include the situs' choice of law rules. But the situs, having the exclusive recognized legislative power to delimit interests in the land (not to mention exclusive physical control) has every confidence that its determination of legal interests will be recognized everywhere. So, when it refers, at its own choice of law level (already having found legislative power in itself), to the law of another state, the situs may disregard how that state would actually decide the case under its "whole" law. Ordinarily", the policy causing the situs to refer to the foreign law will be best served by a reference only to the internal law. For example, when the situs provides that the formal sufficiency of a deed drawn elsewhere shall be determined by the lex loci, the controlling consideration is a general policy which favors upholding deeds, coupled with a presumption that the instrument is more likely to conform to local formalities than to those of the situs. There is no basis for including conflicts rules in the reference to lex loci, unless one makes the ordinarily unwarranted assumption that in framing the instrument the parties themselves were guided by the conflicts rules of lex loci.

Because the "sitting and judging" brand of renvoi had its origin, at least in English law, largely in the field of succession to movables, the question of the applicability of the situs rule to tangible chattels is important for our

12. See Briggs, The Dual Relationship of the Ralles of Confict of Lates in the Strecession Field, 15 MIISs. L.J. 77 (1943).

13. See Briggs, The Jarrisdictional-Choice-of-Law Relation in Confiets Rules, 61 HARv. L. REv. 1165, 1177 et seq. (1948).

14. This reason for the reference is not always made obvious when discussed by the courts. But Restateareat, CoNfuicts of LAws $\$$ (1934), makes explicit this objective. And Cook agrees that, with the situs" exclusive control, it is the "convenient" thing to do. Cook, The Logical and Legal Basts for the Conflict of Laws 65 (1942). Also sce Picotte, Validity of Deed Gicen Under Compulsion of "Forcign" Court, 12 Mosit. L. Rev. 59 (1951). 
analysis. Does the English common law recognize ultimate exclusive power in the situs to delimit interests in movables? A situs rule does dominate the entire field of tangible goods in the United States. ${ }^{15}$ Certainly, many of the European countries recognize this ultimate power. ${ }^{16}$ And on numerous occasions the English courts have recognized such a jurisdictional rule for various purposes. They have declared that the mere presence of a chattel bestows a power on the situs law to effect a transfer of title. ${ }^{17}$ In several circumstances they have recognized a power in the situs to determine whether property should be classified as movable or immovable. ${ }^{18}$ This power to classify property as immovable, in effect, gives the situs power to delimit interests in all kinds of property. ${ }^{19}$ The English courts concede exclusive power in the situs to administer and to distribute movables, ${ }^{20}$ and on at least two occasions they have explicitly laid down a controlling situs rule for movables. ${ }^{21}$

The most convincing proof that England does have a situs rule for movables is a series of recent cases determining the effect of confiscation decrees of foreign governments. ${ }^{22}$ Throughout these cases there runs a perfectly consistent thread: as to property over which it had effective control, England exercised a free discretion to determine whether the confiscation statute of the foreign country was of such a character that. England was disposed to recognize it; but as to property sitused in the confiscating state, that state

15. See Briggs, The Dual Relationship of the Rules of Conflict of Lazus in the Succession Field, 15 Miss. L.J. 77 (1943), with cases and authorities there citcd; 2 Beale, Conflict of Laws 1031 (1935); Gcodrich, Handbook of the Conflict of Laivs 504 (3d ed. 1949).

16. Perhaps the clearest expression of this power is found in German law, in Bürgerliches Gesetzbuch, Einführungsgesetz $\S \S 27,28$ (13th ed., Palandt, 1954). After $\S 27$ expressly adopts the renvoi in a number of cases, including inheritance, $\$ 28$ bows to any contrary rule existing at the situs of property, real or personal.

17. Cammell v. Sewell, 5 H. \& N. 728, 157 Eng. Rep. 1371 (Ex. 1860).

18. Johnstone v. Baker, 4 Madd. 474n., 56 Eng. Rep. 780n. (Rolls Ct. 1817) ; Jerningham v. Herbert, 4 Russ. 388, 38 Eng. Rep. 851 (Rolls Ct. 1829) ; Allen v. Anderson, 5 Hare 163, 67 Eng. Rep. 870 (V.C. 1846) ; In re Hoyles, [1910] 2 Ch. 333, aff'd, [1911] 1 Ch. 179 (C.A. 1910).

19. Professor Beale's attempt to explain away, or to brand as unsound, decisions ruling to this effect cannot be sustained. Compare 2 BEALE, Conflict of Laws 933 (1935), with Cheshire, Private International Law 548-9 (3d. ed. 1947).

20. Attorney-General v. Dimond, 1 Tyrw. 243, 248-9 (Ex. 1831); In re Ewin, 1 C. \& J. 151, 155, 148 Eng. Rep. 1371 (Ex. 1830).

21. Lynch v. Provisional Gov't of Paraguay, L.R. 2 P. \& D. 268 (1871) ; In rc Aganoor's Trusts, 64 L.J. Ch. 521 (1895).

22. A. M. Luther v. James Sagor \& Co., [1921] 3 K.B. 532 (C.A.); Princess Paley Olga v. Weisz, [1929] 1 K.B. 718 (C.A.) ; Banco de Vizcaya v. Don Alfonso de Borbon y Austria, [1935] 1 K.B. 140 (1934) ; Lorentzen v. Lydden \& Co., [1942] 2 K.B. 202 (1941) (expropriation) ; Frankfurther v. W. L. Exner, Ltd., [1947] 1 Ch. 629. Although this article does not attempt to establish the situs as a jurisdictional rule for all transactions in tangibles, these confiscation cases show the wide range of influcnce which the practice of using the situs rule jurisdictionally, with a choice of law rule stabordinated to it, has on the English courts. 
had plenary power to confiscate. ${ }^{23}$ The English courts ruled invalid attempts by the Spanish Republican Government to claim deposits in an English bank belonging to King Alphonso of Spain. ${ }^{24}$ They declared the seizure by the Nazis of an Austrian merchant's business null and void as to credit balances in England.25 They held that Russian nationalization decrees could not effect a transfer of property or extinguish a debt located in England." But they chose to recognize the power of the Norwegian Government to sue for damages on a charter contract found to have been sitused in England when a requisitioning act was passed.2T And they were apparently willing to apply that act to ships

23. The traditional analysis is that each court seeks to apply those "choice of law" rules generally agreed upon by "international comity," except when to apply them would violate a special public policy in the particular case. $R e$ Bischoffsheim, Cassel v. Grant, [1948] 1 Ch. 79 (1947), states it almost in this manner, though the case actually reveals strikingly to what extent an exclusive recognized power in the situs is what gives validity to decisions determining interests in personal property. The court ruled that the law of the domicil of origin determines whether a claimant under a will is legitimate for the purpose of inheriting personal property located in England. In dictum it stated that the only exception to the rule that domicil determines legitimacy is for controversics involving interests in English land. The criticism leveled at this case by various writers that it incorrectly states the English law governing both marriage and legitimacy, even if justified, makes it no less striking a demonstration that the situs may choose either way. See also Briggs, Utility of the Jurisdictional Principle in a Policy Centered Conflict of Lawes, 6 VANd. L. Rev. 667, 705 (1953). Cf. Fatconbrirge, Essays o: tue Confuct of Laws c. 39 (2d ed. 1954) ; Morris, Confict of Lazis-Legitimary, 12 Conv. \& Pron. Law. 223 (1948); Mann, Legitimacy and the Conflict of Law's, 64 L.Q. REv. 199 (1948).

See also, Rabel, Situs Problems in Encuy Properly Mcasures, 11 L.wW \& Cosicssp. ProB. 118, 122 (1945), pitting "territorialism" against "public policy." It is implicit in our thesis that any analysis where policy operates only in special cases must be rejected. Further, Rabel fails to recognize that the only law in a position to make its public policy effective is the situs.

24. Banco de Vizcaya v. Don Alfonso de Borbon y Austria, [1935] 1 K.B. 140 (1934).

25. Frankfurther v. W. L. Exner, Ltd., [1947] 1 Ch. 629. Both this case and the King Alfonso case, supra note 24 , state, as an alternative ground for refusing to recognize the confiscatory decrees of the foreign government, that English courts will not enforce the "penal" decrees of a foreign state. But they were able to apply this principle only after they decided that they were in a position to talk as the situs of the expropriated debt. In expropriation cases, the domicil of the debtor is regularly selected as the situs, and the claim is held to be beyond the "territorial" control of the expropriating country. Because the largest measure of effective power over the interest lies in the debtor's domicil, it can make its judgment stick. Cf. Rabel, Situs Problems in Encmy Properfy Mfcastures, 11 LAw \& Contearp. Prob. 118, 125 et seq. (1945).

26. In re Russian Bank for Foreign Trade, [1933] $1 \mathrm{Ch}$. 745, 767: "If the debt was primarily recoverable in London, I am of opinion that it was not affected by the Sovict legislation, even though it was due to a person who was a Russian subject at the date of the nationalization decrees. Its locality must be taken to be the place where the debt was in the ordinary course recoverable ...."

27. Lorentzen v. Lydden \& Co., [1942] 2 K.B. 202 (1941). Although Loreniscn emphasizes the fact that the requisitioning decree, by its own terms, intended to operate extra-territorially, the Exner case, supra note 25 , involving a similar decree, malies it clear that England exercises its legislative power when it is the situs and malies a free "choice of law" : it refused to give effect to the Nazi confiscation decree but chose to give effect to the 
being built in England on private contracts with Norwegians. ${ }^{28}$ On the other hand, the English courts felt themselves compelled to uphold title in a purchaser from the Russian government of cabinet wood which was situated in Russia when confiscated by that government. ${ }^{20}$ The only condition apparently required by the English courts before validating the divestment of property by a foreign situs state is that the divesting state have at least a de facto "recognition status."30

Nevertheless, in cases involving succession to movables, the English courts have applied a different rule. They state that "the law of the domicil governs succession to movables," quite as though they were unaware that a situs rule controls movables in many circumstances. ${ }^{31}$

If two rules for tangibles exist side by side in English law, either they are in basic conflict with each other, or they serve fundamentally different purposes. $^{32}$ The following discussion assumes that two rules do co-exist and that they fulfill distinct functions : The situs rule is jurisdictional in character, while the rule referring to domicil is strictly a choice of law rule. But whose choice of law is it? Invariably, English courts, always aided and abetted by students considering the problem (with one notable exception ${ }^{33}$ ), have assumed that the domicil rule is a part of the English law for the English court, sitting

Norwegian decree. The court in $L y d d e n$ relied heavily on Anderson v. N.L. Transandine Handelmaatschappil, 28 N.Y.S.2d 547 (Sup. Ct. 1941), aff'd, 289 N.Y. 9, 43 N.E.2d 502 (1942). New York has consistently asserted its exclusive power as the situs, uniformly rejecting all attempts by foreign governments to exercise any authority over "local" property, tangible or intangible. United States v. Moscow Fire Ins. Co., 280 N.Y. 286, 20 N.E.2d 758 (1939), and cases there cited. See also Matter of Good, 304 N.Y. 110, 106 N.E.2d 36 (1952). But the Anderson case gave full effect to a 1940 Netherlands decree "permitting" title to corporate securities, sitused in New York and owned by a Dutch corporation, to pass to the Dutch government. In doing so, it relied on Stone's concurring opinion (stupported by Cardozo and Brandeis) in United States v. Belmont, 301 U.S. 324, 333 (1937), insisting that this type of case must be controlled by New York's choice of law rule, as the situs. United States v. Pink, 315 U.S. 203 (1942), is not contra in ruling that the policy of the Federal Government, expressed in a claims settlement with Russia must prcvail over New York policy with respect to local property: the issue there was an alleged conflict of policy between state and federal law.

28. See Lorentzen v. Lydden \& Co., [1942] 2 K.B. 202, 216 (1941). Also see Civil Air Transport Inc. v. Central Air Transport Corp., [1953] A.C. 70 (P.C. 1952).

29. A. M. Luther v. James Sagor \& Co., [1921] 3 K.B. 532 (C.A.). Accord: Princess Paley Olga v. Weisz, [1929] 1 K.B. 718 (C.A.).

30. See Re, Foreign Confiscations in Anglo-American Law (1951). In arguing that "recognition" has been overemphasized, Re recognizes that the situs of movables has exclusive legislative jurisdiction. Id. at 42-9. Cf. Civil Air Transport Inc. v. Central Air Transport Corp., [1953] A.C. 70 (P.C. 1952).

31. See, e.g., In re Duke of Wellington, Glentanar v. Wellington, [1947] 1 Ch. 506, 513: "[I]t is the clear rule of English law, for which at this date no authority need be cited, that the distribution of the distributable residue of the movables of a deceased is in general governed by the law of his domicil at the time of his cleath."

32. See Briggs, The Dual Relationship of the Rules of Conflict of Lazes in the Succession Field, 15 Miss. L.J. 77, 79 (1943).

33. Abbott, Is the Renvoi a Part of the Common Law?, 24 L.Q. Rev. 133 (1908). 
merely as a formm, to apply. However, if these two rules exist at the same time in the English law, logical consistency and functional harmony compel the choice of law rule to be subordinated to the jurisdictional rule. In the majority of succession cases the forum and the situs agree on domicil as the choice of law and it does not matter where the forum thinks it gets the rule. But, if the situs has a different choice of law rule, c.g., nationality, this choice of law rule must be applied by the forum, or else the forum repudiates its jurisdictional rule looking to the whole law of the situs. It is in this situation that the forum's error in considering the domicil rule its own becomes really serious. ${ }^{34}$

The validity of the foregoing analysis can be demonstrated by considering two recent English cases. In Kotia v. Nahas ${ }^{35}$ the forum is the situs; in In re Duke of $W_{\text {ellington }}{ }^{36}$ it is not. The latter involves both foreign land and movables, while Nahas in effect, involves only local land. As has been stated, this is an extremely important difference.

\section{IN RE DUKe OF VELLINGToN}

In the more recent of these two cases, In re Dukc of II'cllington, three heirs made conflicting claims to movables and immovables sitused in Spain. The Sixth Duke of Wellington, an English national domiciled in England, also held a Dukedom in Spain. He made separate wills. One left all the property in Spain to the heir acquiring both the titles of Duke of Wellington and Duke of Ciudad Rodrigo. The other disposed of all the testator's English property. When the Duke died, it developed that no one person took both titles. Therefore, two questions of construction were before the English court which probated both wills: Did the Spanish will fail for want of a devisee? If so, should the Spanish property be distributed by the law of intestate succession or under the residuary clause in the English will? Though it is said that prior to Wellington renvoi was never applied to questions of construction, ${ }^{3 \pi}$ the court assumed that, under the common law rule that the situs governs interests in land, Spain's whole law should be looked to for the answer to these two questions. $^{38}$ The Spanish Code provided generally that movables should be governed by the law of the country of their owner, and immovables, by the law of the situs, but further declared that, for succession purposes, cither intestate

34. In the United States, two states have repudiated the domiciliary rule in favor of the situs' succession rule, and it is quite generally conceded that movables sitused there must be governed accordingly. Mrss. Code ANN. $\$ 467$ (1942) ; ILL. Stax. Ax.. c. 39, 11 (SmithHurd, 1935).

35. [1941] A.C. 403 (P.C.).

36. In re Duke of Wellington, Glentanar v. Wellington, [1947] $1 \mathrm{Ch}$. 505, aff'd, [1948] 1 Ch. 118 (C.A. 1947).

37. See Morris, Renvoi, 64 L.Q. Rev. 264, 266 (1948). Cf. Clarke v. Clarke, 178 U.S. 186 (1900), where an ineffective judgment resulted when $F$ failed to look to the situs for guidance in the question of construction whether the provisions of the will effected an equitable conversion of the land willed.

38. In re Duke of Wellington, Glentanar v. Wellington, [1947] 1 Ch. 506, 514. 
or testamentary, the order of succession, inheritance rights, and intrinsic validity of the disposition of all kinds of property, should be governed by the national law of the decedent. ${ }^{30}$

\section{Spanish Immovables}

The court first dealt with the Spanish real estate. Uncritically, it interpreted the reference in England's situs rule to be for the purpose of "sitting and judging as would the Spanish courts." To support this view, it relied ${ }^{40}$ on a statement by the Privy Council in Kotia v. Nahas, ${ }^{11}$ which involved only local land, and it cited a series of earlier English decisions involving the question of succession to movables. ${ }^{42}$ The court stated the next question to be whether, when the Spanish statute referred to the deceased's national law, it intended to include the national law's conflicts rules. In its own words: "does Spanish law recognize and apply the doctrine of renvoi?"43 It found no authoritative decision by the Spanish Supreme Court and only two cases from inferior courts, not binding in any way on other Spanish courts. Furthermore, it found the authorities on Spanish law diametrically opposed. However, several leading commentators, including the President of the Spanish Supreme Court, seemed to agree that the purpose for selecting the law of nationality as an exception to Spain's general rule that the law of the situs governs immovables was to "preserve the unity and universality of succession." 14 The court also was satisfied from the evidence that, before the enactment of the Code, Spain had been generally influenced by the continental doctrine that a reference to the law of nationality in succession cases is always to internal national law. With no other basis available for determining whether a Spanish court would "accept the renvoi," the English court decided the question in the light of Spain's apparent policy reason for referring to national law-a most happy and reasonable, though exceptional, basis for decision. Presumably because the simplest way to achieve "unity" of succession would be for all situses to refer to the dispositive rule of the national law, the court ruled that Spain would refer directly to the internal law of England and would not accept the renvoi from English law. ${ }^{45}$ It concluded that the validity of the wills must be determined according to English law. 46

Both the court and counsel have been severely criticized by Morris for conceding that the word "law" in England's rule, that the law of the situs

39. Codigo Civil Espanoz art. 10 (1942).

40. In re Duke of Wellington, Glentanar v. Wellington, [1947] $1 \mathrm{Ch} .506,514$.

41. [1941] A.C. 403 (P.C.).

42. The cases cited are: Collier v. Rivaz, 2 Curt. 855, 163 Eng. Rep. 608 (Ecc. 1841); Casdagli v. Casdagli, [1919] A.C. 145 (1918); Re Ross, Ross v. Waterfield, [1930] $1 \mathrm{Ch}$. 377 (1929); Re Askew, Marjoribanks v. Askew, [1930] 2 Ch. 259.

43. In re Duke of Wellington, Glentanar v. Wellington, [1947] 1 Ch. 506, 514.

44. Id. at 520 .

45. Id: at 523 .

46. Ibid. 
governs, included the conflicts rules of the situs. ${ }^{47} \mathrm{~A}$ brief examination of this criticism should point up the error of many writers who continue to oppose the inclusion of the situs' conflicts rules.

Morris maintains that, under English decisions, when an English court has adjudicated interests in an estate containing both foreign and local land, it has just as much "jurisdiction to determine questions of title to the foreign immovables," as to the local land.48 Apparently he assumes that a judgment based on this "jurisdiction" would be effective, just as it is often assumed that a judgment on a contract or trust indirectly affecting foreign land is effective under the rule of Penn v. Lord Baltimore. ${ }^{49}$ Both assumptions pay no heed to the distinct possibility that, if the English court determines interests in Spanish land contrary to Spanish law, its decree may be a lrutum fulmen in Spain, the only place where its effect is important. ${ }^{50}$ The English courts and commentators have long recognized the possibility of frustration in seeking extraterritorial recognition of an in personam decree, although one judge has advocated exercise of this equity jurisdiction as long as the courts can get away with it:

"If indeed the law of the country where the land is situate should not permit or not enable the defendant to do what the Court might otherwise think it right to decree, it would be useless and unjust to direct him to do the act; but when there is no such impediment [in the foreign law] the courts of this country, in the exercise of their jurisdiction over contracts made here, or in administrating equities between parties residing here, act upon their own rules . ...."

47. Miorris, Renzoi, 64 L.Q. Rev. 264, 265 (1948). Compare Jennings, Reveoi, ot L.Q. Rev. 321 (1948) (answering Morris' criticisms), ziith Falcombnuge, Essars 0: TnE: CoNfutct of Laws 231, 231n.(f) (2d ed. 1954). Jennings correctly states the problem of what law should characterize "nationality" in Spain's choice of law rule, and properly insists that the law of the situs, Spain, must characterize it.

48. Morris, supra note 47 , at 268.

49. 1 Ves. Sr. 444, 27 Eng. Rep. 1132 (Ch. 1750).

50. See Morris v. Chambres, 3 De G.F. \& J. 583, 584, 45 Eng. Rep. 1004 (Ch. 1861).

51. Ex parte Pollard, Mont \& C. 239, 250 (1840). For a comment on this practice see Gordon, The Converse of Pemn v. Lord Baltimore, 49 L.Q. Rav. 547, 549 (1933). The practice, however, has been reaffirmed in a modern decision: "the Court, in virtue of its Chancery jurisdiction in personam, enforces equities in regard ty furcign land where the mortgagor company is within the jurisdiction ... and in delermining zohether there is an equity the Court regards English, not foreign law, and if according to English law there is an equity, e.g., if for valuable consideration a company agrees to give a charge on foreign property, the Cout will enforce it, allhough the equity may be one not recognized by the lex loci rei sitae ...." In re Anchor Line, [1937] 1 Ch. 483, 488, quoting approvingly British So. Africa Co. v. De Beers Cons. Afines, [1910] $1 \mathrm{Ch}$. 354,387 (italics added). Presumably, this practice originated in the theoretieal territorial limitations on the chancery court's jurisdiction and in the supposed special nature of the law it administered. An equity decree being in personam, is not supposed to operate ex:traterritorially, by its own force. Historically, it was not supposed to have any standing in a foreign court at all, since it operated as a quasi-administrative order, dispensing "the King's justice." The King's justice, quickly became identified with "universal justice," originating independently of the "will" of any particular sovereign, and founded en "natural justice." These principles seemed genuinely international in character. Hence, 
A leading Canadian case supplies empirical proof of the fallacy of Morris' position.52 A Canadian court, as the situs, flatly rejected the contention that it should enforce as a matter of course a California court's decree ordering a defrauding defendant to convey title to Canadian land. The court quoted the above passage of English judicial opportunism, ${ }^{53}$ and then expressed its view of the common law:

"The Courts of California therefore must be assumed to have based their judgments on California law, without being influenced by any consideration of the effect on the title, of the contract and of equities arising from it and what followed, according to the law of British Columbia, and without any regard to the statute of British Columbia bearing on the conveyance ...."

The court held that both the right to specific performance and the existence of any equitable title to land must be determined by the ultimate exclusive jurisdiction of the situs. If this is true of an in personam action, it is all the more true of an action intended to affect title directly, such as Wcllington.

Finally, a line of United States Supreme Court decisions refutes the power of a state to disregard the law of the situs in determining interests in land. For example, the problem in Clarke $v$. Clarke ${ }^{56}$ was remarkably similar to that in Wellington. At a probate proceeding in South Carolina, the deceased's domicil, the court had to decide whose law should be used for construction of a will devising Connecticut land. The South Carolina court construed the will by its own law, and concluded that the will effected an equitable conversion of Connecticut land. $\mathbf{5 7}$ It ordered the executor to sell the land and to distribute the proceeds according to the law of South Carolina. The theory of the court was apparently that the land had been converted into personalty immediately upon the death of the testator, and that by the South Carolina choice of law rule, the proceeds should pass by the law of the domicil. The Connecticut courts refused to give full faith and credit to the South Carolina decrec. ${ }^{\text {68 }}$

long after the law courts had begun to make "choices of law," equity considered it to be beyond the purposes for exercising its jurisdiction to utilize a foreign law. See Graveson, Choice of Law and Choice of Jurisdiction in the English Conflict of Lazes, 28 BRIT. Y.B. Int'l L. 273, 277 (1951). Cf. Nussbaum, Principles of Private International. LAw 192 et seq. (1943). However, the assumption that an equity decree is inherently effective does not answer the ultimate question: whose legislative power is it that actually controls the right to enjoyment of land?

52. Duke v. Andler, [1932] Can. Sup. Ct. 734.

53. Id. at 740 .

54. Id. at 742 .

55. See Briggs, The Jurisdictional-Choice-of-Law Relation in Conficts Rulcs, 61 HARv. L. REv. 1165, 1179 et seq. (1948), analyzing a number of representative cascs.

56. 178 U.S. 186 (1900).

57. Clarke v. Clarke, 46 S.C. 230, 24 S.E. 202 (1896).

58. Appeal of Clarke, 70 Conn. 195, 39 Atl. 155; 70 Conn. 483, 40 Atl. 111. (1898). Baldwin, $J$., expresses the basis of the situs' exclusive jurisdiction in terms of governmental interest rather than formal territoriality: "Succession to the real estate of a deceased person is regulated at the will of the sovereign within whose territory it is 
They held instead that there had been no equitable conversion, and decreed that the land should be inherited under Connecticut law. The United States Supreme Court did not hesitate to affirm the Connecticut decree:

"It is a principle firmly established that to the law of the State in which the land is situated we must look for the rules which govern its descent, alienation and transfer, and for the effect and construction of wills and other conveyances."

This line of Supreme Court decisions is particularly significant because it converts common law doctrine into constitutional dogma, notwithstanding the efforts of counsel and publicists to persuade the Supreme Court that, whatever the common law limits on the power of a court to affect interests in foreign land, the Constitution should be deemed to enlarge that power. ${ }^{60}$

Sitting and judging as would the court at the situs and applying the situs' conflicts rules give the greatest measure of assurance that a judgment will not be a brutum fulmen there. The only alternative is for the non-situs court to refrain from exercising jurisdiction in the matter. Thus, Morris' criticism of the Wellington case is quite surprising, especially considering the real position of Cook and Falconbridge, both of whom he cites in support of his view, and both of whom agree that, at least as a matter of $F$ 's convenience, the situs' conflicts rules should be included in a reference to the law of the situs when interests in land are directly involved. ${ }^{61}$

As to Spanish land, the Wellington court's procedure followed closely what we have suggested is the proper practice. It recognized exclusive power in the situs to delimit legal interests in the land and "sat as the court at the situs,"-including Spain's choice of law rule in its reference-in order to

embraced. It has always been regarded as a matter of grave political consequence.... . Ownership of land controls its occupancy, and largely influences the character of the population. It determines the source to which governments ordinarily look for their surest, if not their principal, means of financial support ...." Id. at 210, 39 Atl. at 159.

59. Clarke v. Clarke, 178 U.S. 186, 191 (1900).

60. See Briggs, The Jurisdictional-Choice-of-Law Relation in Conflicts Rules, ol HARV. L. Rev. 1165, 1179, and n.40 (1948).

61. Faiconsbidge, Essays on the Conflict of Laws 180 (1st ed. 1947) : "It would appear that as regards interests in immovables it is logical, and indeed inevitable, that a court sitting in a country other than that of the situs should acquiesce in whatever the forum rei sitae has decided or would decide .... Also, as regards interests in movables, there is much to be said on principle in favour of the same view, that is, that overriding effect should be given to the lex rei sitae . . . " COOK, THE LoGICAL Ard LEGAL BASES FoR THE CONFLict of LAws 253 (1942): "if the question as to who owns or is entitled to the possession of a piece of 'land' in one state is raised in the cuurts of another state, it seems obvious that it is desirable or convenient fur the court in this other state to inquire what the courts of the state where the 'land' is would say about the matter, and thereby bring about uniformity of decision." See also Lorenzen, Thic Renvoi Doctrine in the Conficts of Laws-M caning of "The Low of A Country;" 27 Yale L.J. 509, 530 (1918). All that these writers are doing is recognizing an exclusive legislative power in the situs, which is not an expression of renvoi at all, though they do not seem to realize it. 
create a right as nearly like that a Spanish court would create as practicable. When the Spanish choice of law rule referred it to national law, the English court answered the question of whether this reference included the national law's choice of law rule in the light of the policy behind Spain's reference. It decided that this policy would be best effectuated by a reference to English internal law and that the Spanish court would not sit and judge as an English court. By this reasoning, if an English court is the situs and refers to foreign law for the purpose of maintaining unitary stuccession, it should look to the foreign state's internal law. ${ }^{62}$ Thus, Wellington does not support the proposition that whenever an English court refers to a foreign law it sits and judges as would the foreign court.

\section{Spanish Movables}

Wellington provides a rare opportunity for observing how, in a single case, the English courts treat the problem of movables and immovables with a common foreign situs. The court did not purport to pay any attention to Spain's statutory provision dealing with movables. ${ }^{63}$ If it had followed the procedure which we have suggested is proper, and which assumes that English law has a situs rule for both movables and immovables, it would have referred to the Spanish law by its jurisdictional rule, and then raised exactly the same questions, and found exactly the same answers for the movables, as it did for the land. Instead, the court dismissed the movables problem with the following observation:

"The testator died domiciled in England, and it is the clear rule of English law, for which at this date no authority need be cited, that the distribution of the distributable residue of the movables of a deceased is in general governed by the law of his domicile at the time of his death." 64

Thus, the court assumed that its own choice of law rule governed movables sitused elsewhere, even though the situs had a different choice of law rule.00 The assumption that the forum uses its own choice of law rule, admittedly the quite general assumption, is usually harmless in a case involving two common law states, because their choice of law rules almost always refer to the law of the domicil. But when a civil law and a common law state are involved, the assumption may result in a brutum fulmen. If a common law forum refers directly to the law of the domicil, it is obviously not creating the same interest as would the civil law situs referring to the law of nation-

62. Cf. Cook, op. cit. supra note 61 , at 264 as quoted in text at note 83 infra.

63. In re Duke of Wellington, Glentanar v. Wellington, [1947] $1 \mathrm{Ch} .506,513$.

64. Ibid. Cf. Falconbridge, Essays on the Conflict of Laws 192 (2d ed. 1954), pointing out that the only court with jurisdiction to adjudicate an estate is the situs.

65. Codigo Crvil Espanol art. 10: "intestate succession as well as testamentary successions shall be governed as regards the order of succession inheritance rights and intrinsic validity of the dispositions by the national law of the person whose succession it is, whatever be the nature of the property and the country in which it is situated." (As translated in In re Duke of Wellington [1947] $1 \mathrm{Ch} .506,510 \mathrm{n} .9$ ) (italics added). 
ality, unless, as in Wellington the deceased is fortuitously both a national and a domiciliary of the same state. The Wcllington court, as forum only, should first have used a jurisdictional rule to refer to the whole Spanish law, and then have used the Spanish choice of law rule to refer to English internal law, as the law of the decedent's nationality. ${ }^{\text {is }}$ Conversely, if England were the situs of movables, and recognized ultimate legislative power in itself, it should use its own choice of law rule, referring directly to the internal law of the domicil.

If this analysis is correct, the state of English law, as described by Morris is particularly disturbing:

"The [Wellington] case is therefore in line with Re Annesley, [1926] Ch. 692, Re Ross, [1930] 1 Ch. 377, and Re O'Keefe, [1940] Ch. 124, in holding that a reference to the lex domicilii or to the lex situs in an English conflict rule relating to succession means the whole of its law including its conflict of laws rules."07

The English decisions make no distinction between cases where England is the situs and cases where her only interest is as the forum: a reference to foreign law is always for the purpose of "sitting and judging." tably, this oversimplified version of the renvoi is being extended from sticcession to movables cases, where it originated, to additional conflicts fields where, at present, there is neither theoretical nor practical justification. ${ }^{69}$

\section{Kotia v. NaHAS}

Another English case, Kotia $v$. Nahas, ${ }^{70}$ decided by the Privy Council before Wellington, is of particular interest for two reasons. In the first place, it is

66. Morris insists that Wynn-Parry, J., in the Irellington case does not tell us, "[b]y what process of reasoning he reached the conclusion that the 'national law" of a British subject is English Law." Mlorris, Revwoi, 64 L.Q. REv. 264, 265 (1948). Jennings provides the answer that the question is only what Spain would consider to be the national law of this particular British subject, and that there was no conflict among the experts on this point. Jennings, Renzoi, 64 L.Q. REv. 321, 322 (1948). Furthermore, "naticnality" must be characterized by the situs since it is a term found in the chuice of law rule of the situs.

67. Morris, Rencoi, 64 L.Q. Rev. 264, 265 (1948).

68. Rapel, The Conflict of Laws, A Cosiparative Study (1945), assumes throughout the discussion of revoi, that the issue for the situs court and a non-situs court are exactly the same, with renvoi serving as an excellent modus ziz'cndi for resolving the conflict between the law of the nationality and the law of the domicil. See also Griswold, Revioi Revisited, 51 Harv. L. Rev. 1165, 1185-6 (1938). But there is no real conflict between the continental and the common law states: both agree that the situs has exclusive legislative power. Therefore, all courts should look to the situs and be guided by its choice of law." .

69. See, e.g., In re Askew, [1930] 2 Ch. 259, in which the English court employs "sitting and judging" renvoi to determine whether a party had been legitimated, under the English rule that the "law of the domicil of the father at birth and subsequent marriage" determines legitimacy. Cf. Re Bischoffsheim, Cassel v. Grant, [1948] 1 Ch. 79 (1947).

70. [1941] A.C. 403 (P.C.). More accurately, as Falconbridge suggests, the Privy Council should not consider itself strictly an "English" court in an appeal from Palestine. 
cited approvingly and relied on by the court in the Wellington case. Secondly, it involved a statute of the situs expressly including foreign choice of law rules in a reference to national law to determine succession.

Nahas was an appeal to the Privy Council from a judgment of the Supreme Court of Palestine. It involved a dispute over succession to land located in Palestine. The decedent's widow claimed under the succession law of Palestine, the situs, which would allow her to take one-half of the estate, with the other half equally divided between the decedent's two brothers. The brothers claimed under the succession law of Lebanon, the domicil and native country of the intestate, which would give the widow one-fourth and the rest to the brothers. Palestinian law provided that succession should be governed by the decedent's national law, i.e., Lebanese law, in this case. ${ }^{71}$ Therefore the issue was: Did Palestine's reference include Lebanon's conflicts rules? If so, the Palestinian court would find itself referred back to its own law because the Lebanese choice of law rule was that the law of the situs determines succession to land. Using the formula that a reference to foreign law is presumably for the purpose of "sitting and judging as would the foreign court." the coutt reasoned that the reference from the law of Palestine, as the situs, to the national law, included the latter's conflicts rules. It concluded that there was no reason in the particular case why it should not accept the reference back to the situs and apply its own internal succession statute which, incidentally, strongly favored the widow. ${ }^{\mathbf{7 2}}$

The brothers argued that the reference from Palestinian law to Lebanesse law must be directly to the Lebanese domestic rule of stuccession, for if the reference included Lebanese conflicts rules, the dreaded circulus incitricabilis necessarily would result. We already have briefly indicated the court's response to this contention. Its answer, however, calls for careful examination in terms of two fundamental questions: Should the situs sit and judge as a foreign court? Should the foreign court sit and judge as the situs?

It is difficult, however, to follow Falconbridge's insistence that it must consider itself strictly a Palestinian court: "Clauson L.J. has allowed himself to slip into the error of imagining that the Privy Council is an English court, whereas in the case under discussion it was merely a Palestine court sitting in England." Falconbridge, Essays on tire Conflict of Laws 223 (2d ed. 1954). Undoubtedly the exact juridical status and function of the Privy Council vary greatly with the part of the Empire from which an appeal comes. But surely one of its basic functions as an instrument of the Crown is to achieve and maintain an element of uniformity - "universality"- in at least some parts of the law involving Empire interests at high policy levels. Nowhere would it seem that such objective might better be sought than in the "private international law" field. And when the appeal comes from a mandated territory under covenant granting the mandatory practically full powers of legislation and of administration, is not the Privy Council very far indeed from being merely a Palestinian court? A recent decision, revealing the Privy Council's own contviction that it has a unifying function in establishing doctrine for different parts of the Empire, is Bakhshuwen v. Bakhshuwen [1952] A.C. 1 (P.C. 1951). This was a property case. Obviously the unifying function is more appropriate still in the conflicts field.

71. Kotia v. Nahas, [1941] A.C. 403,412 (P.C.).

72. Id. at 414-15. 


\section{Should the Situs Sit and Judge as a Foreign Court?}

It is extremely improbable that Palestine intended to "abdicate" or "delegate" to the national law ultimate legislative power over land sitused in Palestine. Although a state has a primary interest in the general welfare of its nationals, almost all legal systems recognize that the governmental interest of the situs in its land is paramount to that of any other nation. Hence, a reference from situs law to national law should be interpreted as a choice of law by the situs at a secondary policy level. On these gencral principles, the brothers' contention that Palestine's reference is directly to intermal national law would be altogether valid, and the initial presumption of the Privy Council that it should always sit and judge as the foreign court ${ }^{73}$ is most unfortunate. However, in this particular case, the language of the Palestinian Code required the court to include the national law's conflicts rules in the reference: " $m$ mll: land and movables of the deceased shall be distributed in accordance with the national law of the deceased .... [W] here the national law imports the law of the domicile or the religious law or the law of the situation of an immovable, the law so imported shall be applied ...."7t This statute supports the court's decision to sit and judge, but it raises the further question of what claims or interests the framers thought they were serving by reference to the whole national law. Of course, Palestine, as the situs, has the legislative power to defer to the whole national law, but one wonders whether the framers of this act were not so bemused by the developing idea of including foreign conflicts rules in a reference that they incorporated the principle without any clear idea of what governing policy they were advancing. If the reference is designed to preserve the "unity" of the estate, the simplest path to that end would be a reference directly to the national law's internal succession rules. To legislate the oversimplified sitting and judging version of renvoi is a much more permanent error than to establish it by judicial decision.

\section{Should the Foreign Court Sit and Judge as the Situs?}

To the brothers' argument that a reference to Lebanon's conflicts rules would create the circulus inextricabilis, with Palestine referring to the whole national law, and Lebanon referring back to the whole situs law, ${ }^{75}$ the Court gave a short answer: it is not necessarily so. Especially since Palestine was the situs of the land, the Privy Council held that the Palestinian court was free to cut the circle on the first reference back from Lebanon, and to apply its domestic law of succession. 70 Though pretending to be "sitting and judging

73. Ibid.

74. Id. at 408 (italics added). The Palestinian statute makes no distinction whatever as to the relative importance of the law "imported" by the national law according to whether it is from the domicil, the religious law, or the situs. It is of the utmost importance for intelligent legislative drafting, and intelligent interpretation, that the supremacy of the situs rule be recognized.

75. Kotia v. Nahas, [1941] A.C. 403,414 (P.C.).

76. Id. at 414-15. 
as the Lebanese court," the English and Palestinian courts did not even ask whether Lebanon would include in its reference to the law of the situs the situs' conflicts rules. ${ }^{77}$ True, there was considerable apparent precedent in English succession cases for the forum to "accept the renvoi" on the initial reference back. But Wynn-Parry, J., did not frame the result in Wcllington in terms of "accepting the renvoi": he made an earnest effort to determine whether a Spanish court would refer to English internal law or would practice "renvoi."

If the Palestinian court had inquired why Lebanon looks to the law of the situs it would almost certainly have reached the conclusion that Lebanon recognizes an exclusive legislative power in Palestine and refers to Palestinian law to create interests which would be valid and effective there. To create such interests, Lebanon would have to employ Palestine's choice of law rules. Thus, the brothers' contention that reference to the whole Lebanese law will restult in the circulus inextricabilis is correct. The proper way for the situs to avoid the circle is to go directly to the foreign internal law in the first place, unless that would not best promote the policy behind the reference.

In these two English cases we find an apparently baffling condition of the law. Both purport to recognize and apply the same doctrine of renvoi. $\mathrm{Wel}$ lington cites Nahas as authoritative precedent. Yet, the application of the doctrine in one case is fundamentally different from that in the other. If these two cases are considered in the traditional manner without regard to the governmental relationship of the forum to the land, they are in irreconcilable conflict except at the level of verbalization of the rule which purportedly controls them. In the language of current conflicts literature, Nahas utilizes the older simple brand of renvoi. ${ }^{78}$ It just assumes that the Lebanese law refers to Palestine's internal law. It "accepts the renvoi" with no realistic study of

77. Ibid.: "[W]hat would the Lebanese courts determine to be the devolution of this particular piece of land in the circumstances stated? The evidence shows that the Lebatnese court would determine that the Palestine law, being the law of the situation, governs the matter ... [T] here is nothing in the law of the Lebanese State to interfere with the application to the case of the law of Palestine, being the law of the situation of the property in question. The Palestine Court must ... be taken to accept the renvoi and apply its own law, as applicable to the case of a Palestinian citizen ...." Not one word, so far as the record shows, was said about the possibility of the Lebancse court referring to the whole law of Palestine, as almost certainly it would do: as non-situs, the Lebanese court stood in the same position as the English court in the Wellington case and that court referred to the whole of Spain's law as the situs.

78. See Falconbridge, Essays on the Conflict of Laws 174 (2d ed. 1954) (calling this a "partial, imperfect or pseudo renvoi," contrasted with sitting as the foreign court which is "total, perfect or integral renvoi"); Griswold, Renvoi Revisitcd, 51 HARv. L. Rev. 1165, 1167 (1938). Cf. Cheshire, Private International Law 87 (3d ed. 19-17) ("sitting and judging" classed as something distinct from "renvoi"). 
what the Iebanese court actually would do in the case. ${ }^{70}$ Hence, contrary to the court's own statement of what it was doing, and in spite of the fact that it was cited as precedent for "sitting and judging" in the IVcllington case, Nahas does not support that type of renvoi. By contrast, W/lington's treatment of land provides a genuine example of an English court doing its utmost to decide the case exactly as would a Spanish court.

It is impossible to frame a single rule of renvoi to apply to both Nahas and Wellington. However, if one looks only a little further, a wholly satisfactory explanation appears. In the Nahas case, in addition to being the forum, the Privy Council was the final appeal court for the situs. Hence, it had no compulsion to decide the case just as would a Lebanese court; it had the final controlling power over the subject matter. Not so in $1 F^{\prime}$ cllington, where the court realized that, for its judgment to have any real effect, it must be acceptable in Spain. In ascertaining their true meaning as precedent, any interpretation of these cases which fails to take into account whether the forum is also the situs is misleading. This failure results in citing the Nahas case as supporting "sitting and judging" renvoi merely because it gives lip service to that formula. If the Nahas court had really sat and judged as a foreign court, it would still be in the circulus inc.rtricabilis. When the Wellington case took the verbal formula from Nahas and actually did follow it with respect to land it produced a completely correct result-but only because of the fundamentally different relationship of the two courts to the land in question.

Thus interpreted, these two cases, though equally purporting to use the "sitting and judging" form of renvoi, support the basic thesis of this study: whether $F$ should sit and judge as the foreign court generally depends upon whether its only interest in the litigation is as a forum, or whether, in addition, it has the controlling governmental interest with exclusive ultimate legislative power.

\section{"Sitting and Judging": The Comarentatons \\ Reaction to "Renvoi Revisited"}

The most effective presentation of the "sitting and judging" formula is Dean

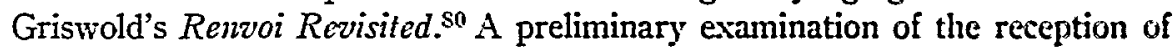

79. But see Falconbringe, Essays on the Coxflict of Laws 220 af seq. (2d cd. 1954), arguing that the language of the statute requires that, when Palestine as the situs finds a reference from the national law to the situs, it "accept the renvoi," i.c., practice "partial renvoi." See note 78 supra. For this, he relies heavily on another clause of the statute, providing that, "if the national law imports the law of the domicile and the latter provides no rules applicable to the person concerned, the law to be applied shall be his national law." But the court did not refer to this clause in interpreting the statute. Furthermore, the court stated clearly that it was going to sit and judge, not fractice "partial renvoi." Finally, Falconbridge's conclusion that a reference from the natiunal law is always to $T$ 's internal law is based on the assumption that "no rules" in the clause he relies on means "no internal rules." It may mean choice of law rules. Or it may" simply" take note of the fact that some laws, e.g., Russian, make no choice of law at all for foreign land.

80. Griswold, Revwoi Revisited, 51 HARv. L. REv. 1165 (1938). 
Griswold's view by the conflicts writers will help both to justify our thesis and to suggest what remains to be done in the way of analysis of "sitting and judging" renvoi.

Though Falconbridge fails to recognize the utility of separating conflicts rules serving a jurisdictional function from those operating at the choice of law level, he does set forth in considerable detail the pitfalls inherent in always "sitting and judging." $\mathrm{He}$ points out that the primary object of the "sitting and judging" formula - to adjudicate interests exactly in the way the foreign court would determine them for this precise property ${ }^{81}$ — cannot really be accomplished :

"It happens, however, under the Anglo-American theory and practice, that there is normally a separate administration in each country in which the de cujus has left assets, so that a judgment in $Y$ with regard to movables situated in $X$ must be a hypothetical judgment, not an actual judgment, and in order to confer jurisdiction upon a court in $\mathrm{Y}$ for the purpose of its hypothetical judgment, the actual situation must be varied by supposing at least that the movables are situated in Y ... so that, in order to make the formula workable at all, construction (a) gives place to construction (b), by a mysterious process of conscious or unconscious transmogrification . . . ." 82

Cook senses something of the misleading character of the "sitting and judging" formula when he declares:

"This brings us to the main point of this paper, one which has been overlooked by practically all courts and writers, namely, that the rule that the 'law' of the situs is to be applied furnishes no guide whatever to a court of the situs, unless it is first assumed that the word 'law' in the rule means in such a case the purely 'domestic' rule of the situs, and not its conflicts rule." 83

Cook would have revealed both to himself and others that there is much more than a semantic problem involved here, had he said simply that the question posed for a court at the situs is a very different one from that posed for a

81. Falconbridge, Essays on the Conflict of Laws 191 (2d ed. 1954). Cf. Cook, The Logical and Legal Bases of the Conflict of LAws $243 \mathrm{n} .8$ (1942), insisting that when the situs looks to another law, e.g., the domicil, to sit and judge as the latter's courts, it must base its decision on hypothetical property sitused in the domicil, rather than the property actually involved. English practice in recent leading cases is open to this criticism. To avoid dealing in hypotheticals the situs court should not put itself in the position of the foreign court.

82. Falconbridge, Essays on the Conflict of Laws 192-3 (2d ed. 1954). The American cases most strongly stressing the control of the situs at death, are those where slaves sitused in $S$ at the owner's death have since been brought into $F$, giving $F$ clear judicial jurisdiction over them. These cases recognize legislative power in the situs. McCollum v. Smith, 19 Tenn. (Meigs) 342 (1838); Jones v. Marable, 25 Tenn. (6 Humph.) 116 (1845). Also see Briggs, The Dual Relationship of the Rules of Conflict of Laws in the Succession Field, 15 Miss L.J. 77, 90 (1943).

83. Cook, op. cit. supra note 81 , at 264 . 
foreign court: each refers to foreign law at a different policy level; hence the rules for each must be framed differently; and, since the situs has exclusive legislative jurisdiction, its solution of the problen must guide all other courts. Of course, he could not say this, because he had long since flatly rejected the legal significance of "legislative jurisdiction."

Rabel joins Griswold, Cook, and a growing number of others in his healthy insistence that the central problem in renvoi is one simply of "policy." But he never deals particularly enough with the various policies involved to recognize that practically all the instances of renvoi occur in fields where there is general agreement that some one state has exclusive legislative jurisdiction of the subject matter and the issue involved. Nowhere does he recognize the existence of the basic policy conflict between the rule that the situs governs all interests of land and movables and those rules which look to the domicil or national law to determine a particular interest. He approves of Griswold's position expressed in the "sitting and judging" formula, and agrees that $F$ is always guided in its reference by its own choice of law rule. ${ }^{86}$

Throughout his discussion of the general problem of renvoi, Rabel assumes, first, that any court is free to look to the domicil or the national law regardless of where property is sitused, and secondly, that the only question for the forum to consider at this point is: Should the reference include conflicts rules ? $^{3 i} \mathrm{He}$ is disposed to answer that question in the affirmative on the ground that "sitting and judging" serves the "policy" behind the reference, i.c., it contributes to international harmony. 88 How far this reasoning carries Rabel is shown by his treatment of illustrative cases dealing with succession to movables, in which the possibility that the situs may have an interest in the issue is not once considered. $^{59}$ In one of these illustrations an English national, domiciled in Germany, left land in Georgia under a will probated in Germany. Rabel says, "The German rule [nationality] refers to English conflicts law which refers to the lex situs. The statute of distribution of Georgia, therefore, is applicable in a German court as well as in England, although German conflicts law itself does not distinguish movables from immovables for the purpose of succession." Of course, to resolve successfully the varying policies of Germany, England, and Georgia, the German court should refer first to the situs law, including

84. See Briggs, Utility of the Jurisdictional Principle in a Policy Centercd Conflit of Lazus, 6 VAND. L. REv. 667, 670 (1953).

85. 1 Raber, The Conflict of Laws, A Coacparative Study 76 (1945).

86. Id. at 72 .

S7. Id. at 78-9. He strongly suggests that a conflicts rule looling to national or domiciliary law expresses what we call a legislative jurisdiction rule, rather than a choice of law rule: "Indeed, the nationality principle does not mean that a foreign national is subject necessarily to the substantive law of his country; it means that the state to which the individual belongs should determine his personal relations ...." Id. at 78 .

S8. Id. at 76.

89. Id. at 79 .

90. Id. at 7S. Actually, German law recognizes the situs of movables and immovables

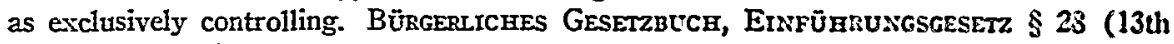
ed., Palandt, 1954). 
its conflicts rules. As long as Georgia agrees with England that its own statute of distribution should control, Rabel's procedure reaches the right result. But suppose Georgia insists that the distribution statute of some other state should apply. Is there any doubt whose conflicts law must prevail?

The traditional analysis, so clearly revealed in Rabel's discussion, takes up a consideration of the issues only at the choice of law level, and assumes that the "policy" expressed there is the only policy. In fact, in the fields of law where renvoi is prevalent, whatever policy may be framed in a choice of law rule is always subordinated to other policies found in the forum's own law and formally expressed in controlling jurisdictional rules. Only by stubordinating choice of law to jurisdictional rules can the policy question be particularized sufficiently to indicate when a reference to a foreign law should include the foreign conflicts rule, and when it should go directly to the foreign intermal law.

\section{Renvoi Again Revisited.}

Subjecting Griswold's use of the "sitting and judging" formula in the succession field ${ }^{91}$ to analysis in terms of the jurisdictional-choice-of-law dichotomy will help to show up the shortcomings of that verson of renvoi. Griswold assumes that the sole object of looking to the law of the domicil is to "apply" that law exactly as would the domiciliary court to this precise estate. He tells us :

"If there is to be uniformity in its distribution, all the courts before which the question may come must agree to follow the rule which will be applied by some one of them. The English rule of the domicil seems to be an expression ... that the court which should control is the court at the domicil.",

Thus, if the domicil would refer to national law, so should all situses, by including the domicil's choice of law rule in their reference to the domicil. ${ }^{\text {gs }}$

Elsewhere, however, Griswold suggests that perhaps what common law courts do in fact is to look primarily to the law of the situs of movables and then find that the situs' whole law looks to the law of the domicil, which agrees that the domiciliary law should be applied: "[A]nd so the New York court [as forum only] is led unerringly [through the situs] to the internal

91. Griswold, Renvoi Revisited, 51 HaRv. L. Rev. 1165, 1184 et seq., 1194 et scq. (1938). There is much underlying agreement in that article with the thesis advanced here. In 1936 the author discussed at some length in seminar in Griswold's presence the five principle fields which most generally support the "dual category" of conflicts rules. This 1936 study was at least one of Griswold's primary stimuli for writing Renvoi Revisitcd. If it were not for the difficulty of reconciling Part VII of that article, discussing the fields where the two kinds of conflicts rules most clearly exist, with the first part, championing "sitting and judging as the foreign court," we could say that our analysis agrees with Part VII so far as it goes.

92. Id. at 1185 . This is a correct consideration of the problem only at the sifus choice of law level.

93. Ibid. 
law of Massachusetts [the domicil] for its disposition of the case." Clearly Griswold intends that the situs shall look to the "whole law" of the domicil. This is in accord with his thesis that a reference to foreign law is alavays for the purpose of "sitting and judging." Thus, the situs, like any foreign court, will find itself in the domicil's internal succession law only if the domiciliary court would apply its own internal rule. If the domicil would look to the law of the deceased's nationality, so should the situs. But what then is added by the suggestion that common law courts really look to the situs if it is assumed that it always is the whole domiciliary law that finally disposes of the case $?^{35}$ Griswold fails to harmonize the bulk of Renvoi Rcvisited with Part VII in which he discusses cases where the courts look to the situs law and are governed by its choice of law rule. ${ }^{90}$ There is a serious inconsistency in his attempt to maintain first, that other courts should be and are guided ultimately by the domicil court, and then to declare that these same courts have perhaps been looking first to the law of the situs all along. By one rule, domiciliary law controls generally. By the other, situs law controls generally. The only way to harmonize the two rules is to make one consistently subordinate to the other.

Griswold recommends the "sitting and judging" formula in the succession field to assure "uniformity" in the sense of passing the estate as a unit-to preserve as nearly as possible the principle of the "universal succession," originating in the Roman law, and still basic to many legal systems. ${ }^{07}$ Yet under Roman law, "universal succession [passed] both rights and debts ... . the latter in such a way as to constitute them the debts of the heir himself, so that the original debtor [the deceased] appears before the creditors in the person of the heir."98 Consequently, however much civil law courts and common law courts may employ the same language to explain a reference to a "personal" law, 99 they cannot possibly have the same ends in view-simply because there is no "universal succession" principle in the common law..$^{100}$

94. Id. at 1194. Griswold also seems to rely on the "vested rights" concept to support the selection of the domiciliary law. Id. at 1186. However, in his illustration, the situs and the domicil are the same state. Griswold's analysis thus describes accurately what this court does, but it is really the state as situs at death, which creates the "vested right," not that state as domicil. Cf. Nussbaum, Principles of Private Intrerational Lay 26 et seq. (1943).

95. If the implications of the cases cited in Griswold, supra note 91, at 1194n.97, were carried out, the exclusiveness of the power of the situs would have to be recognized.

96. Griswold, supra note 91 , at 1194 et scq.

97. Griswold, supra note 91 , at $\mathbf{1 1 8 5}$.

98. Sohar, The Institutes 505 (3d ed., Ledlie's transl., 1907). law.

99. The phrase "personal law" will be used to include both national law and domiciliary

100. Common law authorities frequently rationalize the selection of the domicil to govern succession to movables on the ground that it is to preserve the "universal succession" of the estate. See, e.g., Holmes, J., in Blackstone v. Aiiller, 18S U.S. 189, 204 (1903): "Universal succession is the artificial continuance of the person of a deceased .... [N]o one doubts that ... the law of the situs accepts its rules of succession from the law of 
But whatever they mean by "uniformity," civil law and common law courts generally agree with Griswold that it is desirable to distribute the movable estate "as a unit" under a single law. ${ }^{101}$

Neither Griswold nor the courts explain how a reference by the forum to the whole personal law is to produce uniformity. If the forum is the situs, it can assure as much uniformity as by a reference to the whole personal law far more simply by going directly to the internal succession rule of the personal law. If the forum is not the situs and it looks directly to the personal law, its judgment may be a brutum fulmen at the situs. ${ }^{102}$ Agreement between a foreign forum and the personal law, without regard to the situs, adds uniformity only if the situs chooses to uphold it. The real obstacles to uniformity are the different situses containing different parcels of the estate. If all the situses agree that the same personal law should govern, real uniformity is achieved by looking first to the law of the situs, including its choice of law rule, and then going directly to the personal law's internal stuccession rtule. ${ }^{103}$

This is not to say that the situs court should never refer to a foreign conflicts rule. Once decisive power in the situs is recognized, the situs may properly apply the personal law's choice of law rule if it feels that all the situses can best achieve unitary succession by such a reference. But this is not aptly

the domicil, or that by the law of the domicil the chattel is part of a tuiversitas . . ." 2 Beale, Conflicts of Laws 1029-30 (1935): "[T] he reasoning of the common law is based upon the fact that not a single thing but an entire estate is passed .... It is desired that the unit be not merely that part of the estate but the entire estate. To accomplish that result, so far as it can be accomplished, the law of the domicil . . . is chosen . . . " Both writers have in mind only the personal estate of the deceased. Because English internal succession law was always applied to land, talk about preserving the "unitary" character of the estate was a pure fiction: the real property of an estate might still be governed by one law, and the personalty by another.

101. See Griswold, stipra note 91 , at 1185 .

102. See Wolff, Private International Law 210-11, 567-75 (2d ed. 1950), criticizing the continental attempt to obtain unitary succession to land by allowing personal law to control. "Is it consistent with justice to establish rules which are necessarily ineffective?" Id. at 569. "Have the claims of $W$ to the house in Copenhagen and of $S$ to the house in Amsterdam [based on a rule of personal law in conflict with situs law] any reality outside the lawyers' files?" Id. at 570 .

Wolf's suggestion that European states should recognize that the situs has the ultimate power to decide whether to give effect to a foreign court's selection of a personal law, is supported by modern multi-partite conventions. See, e.g., Montevideo Convention art. 44, 45 (1940), quoted in 8 Hudson, International Legislatron 523-4 (1949); Hague Convention on Conflict Rules Concerned with Guardianship art, 6 (1902), quoted in [1902] Descamps \& Renault, Recueil Internationales des Traités du XX' Siv̀cle 227; Hague Convention Concerning the Effects of Marriage art. 7 (1905), quoted in 6 MAkTENs, Nouveau Recuerr Gennerat de Traites, trotsième série 485 (Triepel ed. 1912). The treaty experience, that it is possible to achieve general agreement only by resort to the situs, and the clearly established law of expropriation, recognizing plenary power in the situs (see text at notes 22-30 supra) combine strongly to establish the situs as the absolutely controlling law internationally.

103. Of course, if one situs selects one personal law, and another situs selects a different one, there will continue to be conflict. 
described as "sitting and judging" as the court of the personal law. For if that state were the forum, its jurisdictional rule would refer it to the law of the situs, and it would never use its own choice of law rule. In contrast to the complete abdication of legislative prerogative effected by a reference from a foreign forum to the situs, ${ }^{104}$ the situs holds a tight rein at all times on the question of how much of the personal law should be included in its reference at its own choice of law level. It is the policy of the situs which dominates every issue, rather than that of the personal law.

One of Griswold's own illustrations gives content generally to the preceding abstract discussion of his treatment of renvoi, and specifically to the question of whether the situs should ever include a foreign conflicts rule in its reference. A German national died, domiciled in France, with movables in England. France and Germany both agree that the national law should determine succession. Although England generally looks to the domicil, should she not accept the national law in this case, since two of three interested countries agree upon that law? 105 By all traditional analysis, including the "sitting and judging" formula, the question is the same for the English court whether it is sitting merely as a forum, or in addition, is the situs. But it is at this point that the traditional approaches fail.

The basic issues become clear when the forum is placed in a fourth state. Suppose suit is brought in Denmark, and the "majority rule" argument is made. Should Denmark seriously consider this argument without taling into account England's law for this precise case? Suppose Denmark decrees that the plaintiff is entitled to the property under the German succession law because both France and Germany agree in that result. When the plaintiff brings an action in England, after administration, petitioning the court to order the administrator to surrender the chattels to him, is there much doult that the English court would assert its power as the situs to deternine succession to movables? Denmark, then, should look first to the law of the situs. And the fact is that probably the great majority of legal systems the world over agree that the situs in such a case is ultimately controlling. ${ }^{100}$

The situs is the only state able to answer the argument that where two of three states involved agree on a particular personal law, the third should apply it too. And in its decision the situs exercises its legislative power; it does not sit and judge. If it favors the "majority rule," it has formulated a special "choice of law rule," strictly part of its own legal system, utilizing the national law, not because either the domiciliary or national court would do so in this case, but rather because they both do so. Of course, if the situs chooses to apply

104. Of course, $F$ must reject efforts by $S$ to claim more jurisdiction than is required by the situs principle. The limitations that $F$ should set on the scope of its juricdictional rules, will be discussed in a paper focusing on -Young v. Masci, 259 U.S. 253 (1933); Scheer v. Rockne Motors Corp., 68 F.2d 942 (2d Cir. 1934); and Cavers, The Tu'o "Local Law" Theories, 63 Harv. L. REv. 822 (1950).

105. See Griswold, Renvoi Revisitcd, 51 Harv. L. Rev. 1165, 1190 (1938).

106. See Wolff, Private International. Law, 210-11 (2d ed. 1950). 
the internal national law, simply because the other two interested states wotld do so, all other courts should do the same. ${ }^{107}$

\section{Application to Russian Law}

A further test of the utility of our analysis is presented by still another illustration in the succession field, advanced by several English antirenvoists ${ }^{108}$ to refute the view that a reference to a foreign law should ever be to sit and judge as the foreign court. These commentators point out that if England, as the situs of movables and the forum, refers to Russia as the domicil of an intestate, it cannot sit and judge as would a Russian court because Russia is peculiar in that it does not apply its stuccession law to foreign sitused property and does not even frame a choice of law rule in such cases. ${ }^{109}$ Of course, the error of these writers, supported by English cases, is the assumption that renvoi, to be valid, requires English courts alveyss to sit and judge as the foreign court in a succession case. As we have shown, they should do so only when England is not the situs and has to refer to the situs' law. In the case supposed, where the forum is the situs, it should go directly to Russian internal law.

In citing Russian succession law to demonstrate the fallacy of the "sitting and judging" formula, Cheshire is on sound ground-but only for this particular case, and not for the reason he gives. Correctly interpreted, the Russian

107. Another special rule may be created for the situation where the deceased, a national of $N$, was domiciled in $D$, with property in $D$ and also in $F$. For its own property, $F$ 's choice of law rule is domiciliary law. For its own property, $D$ 's choice of law rule is the national law. When $F$ has occasion to consider whether its reference to $D$ 's law should include $D$ 's choice of law rule, $F$ may recognize a cumulative' governmental interest in $D$ as domicil and as situs, and decide to be guided by $D$ 's choice of law rule, at least if $D$ refers only to internal national law. Whether it will prove practical to go this far in franing highly individualized choice of law for the precise case, can be determined only on the basis of more experience in that procedure than we now have.

108. See Cheshire, Private International Law 101-2 (3d ed. 1947); Dobrin, The English Doctrine of the Renzoi and the Sovict Law of Succession, 15 Brit. Y.B. INT'L L. 36 (1934). Cf. Griswold, supra note 105, at 1196n.105. The most important fact revealed by our analysis may be the extremely large measure of agreement presently existing among all writers, both those formally favoring and those formally opposed to renvoi. Perhaps this is nowhere better exemplified than by Cheshire. Although adamently opposed to any and all forms of renvoi, he concludes his very thorough and extended dentunciation with the assertion that there are some five fields in which the English courts will include conflicts rules in a reference to foreign law. These are precisely the fields in which we find the best evidence of the dual category of conflicts rules. And Cheshire antlyzes these fields almost exactly in the terms of our thesis : he selects a single legal system as governing each field and declares that foreign courts will include that system's conflicts rules in a reference to it. See CheshiRe, op. cit. supra, at 85-129, particularly at 127-8. Furthermore, it is hard to find a more effective justification for this practice in these ficlds than that given by Cheshire. Id. at 291-2, 481 .

109. If the Russian courts were to develop the practice of exercising judicial jurisdiction in appropriate cases, but continued to look to the situs as having exclusive Icgislatiz'c jurisdiction, they would employ what we consider to be the proper practice. Sce Griswold, supra note 105, at 1196n.105. 
law problem illustrates half of our thesis : generally, the situs should not consider itself "sitting and judging" as the court of the personal law. Since it will obviously enforce its own judgment, the English court has no need to sit and judge as the foreign court, and is perfectly free to go directly to the Russian internal rule even though a Russian court would find it had "no law" to apply to the case. But this Russian example proves nothing whatever as to what a foreign forum should do when it refers to the situs' rule. Cheshire overgeneralized, with the resulting serious error.

Examination of the "sitting and judging" formula suggests that there is common ground upon which the extreme anti-renvoists and the sitting-andjudging renvoists can resolve their differences. The arguments of the former often are based on a reference from the situs court, and those of the latter on a reference from a foreign forum. The "sitting and judging" formula is an acceptable one for only a very small percentage of those cases which involve interests in land or chattels and in which the court decides to refer to the law of another state. Common law courts never attempt to adjudicate interests in foreign land except indirectly through their personal control over the defendant, or occasionally, as in the Wellington case, through the construction of a will or a trust instrument. Similarly, a forum will not try to determine who shall inherit foreign movables, except in these situations and in the additional rare one where movables have found their way into the forum and a dispute arises over their ownership.110 Nearly all cases containing these questions arise at the situs, though the situs may often "choose" to utilize the law of another state. It is therefore difficult to follow Rabel's assertion that "sitting and judging like a foreign court," as practiced by the English courts, is "a praiseworthy contribution to international harmony . . . ."111

The "sitting and judging" formula, if applied as a matter of course in the succession field, is unacceptable for two reasons: At no point does it reveal the fact that most legal systems have recognized, often inarticulately, the ultimate exclusive legislative jurisdiction of the situs to determine succession to tangibles. And even were this recognized by the "sitting and judging" formula, the initial reference to the law of the situs would still be unsatisfactory if, in accordance with that formula, the reference from the situs were to the whole personal law.

\section{Conclusion}

The central thesis of this paper is that whether $F$ 's reference to $S$ 's law should include $S$ 's conflicts rules, depends on $F$ 's legislative interest in the

110. See note 82 supra.

111. Rabel, The Conflict of Laws, A Cosparative Study 76 (1945). Wolff is much more cautious, saying that harmony may result between two states, and, in the case of transmission, between three. WolfF, Parate Internations. LAW 201 (2d ed. 1950). 
litigation. ${ }^{112}$ No real conflict between the two laws can arise in the succession field, if the court follows the procedure dictated by its own controlling policy considerations. If $F$, as non-situs, having no legislative interest in the suit, refers to $S$ 's law from its own "power recognizing" level, it will include $S$ 's "choice of law" rule in its reference, and, generally, try to apply $S$ 's law as would the $S$ court. However, if $F$ finds the paramount governmental interest in itself, it will refer to $S$ 's law only from its own "choice of law" level, and the reason for the reference to foreign law will usually cause $F$ to refer directly to $S$ 's internal law.

Thus, the renvoi, in terms of the problems it is supposed to raise, and its claimed theoretical offensiveness, is a false issue in those fields most uniformly cited as illustrating the doctrine. Reference to foreign conflicts rules cannot result in irreconcilable conflict between two legal systems if such reference is generally confined to those situations where the forum and the law referred to agree that the latter has exclusive legislative jurisdiction.

112. For a description of the utility of this analysis in solving the related problem of characterization, see Briggs, Utility of the Jurisdictional Principle in a Policy Centered Confict of Laws, 6 VAND L. REv. 667, 700-06 (1953). 


\section{THE YALE LAW JOURNAL}

Voluare 64 DECEMBER, 1954 Number 2

\section{BARRY R. BRYAN Article and Book Review Editor}

IRVING J. ALTER Peter W. Anson Rosert W. BerEND DANIEL MI. Berger MUrRy D. Brochin Richard C. Camin Thom Donald J. Cohn JoHN W. CoLleran ALAN P. Colodny EDarund V. Conway Geraid M. Doppelt David A. Drexier S. GoRdon ElKINS JOSEPH M. FIELD Barry H. GarfinkeL

\section{EDITORIAL BOARD}

Jerodre A. CoHeN Editor-in-Chisef

William H. Dearpsey, JR. Thomas F. Nelson Gordon B. Sprvack Note and Comment Editors

\author{
Gerald WALPIN \\ Maraging Editor
}

Charles S. Hatght, JR.

ROBERT J. HARRIS

George C. Hastrings

Ira MíchaEL Heyaras

Alexander P. Hofrarann

Charles D. Isaac

David B. Isbelz

Lawrence R. Kiein

NOEL ARNOLD LEVIN

Charles S. Mecheas, JR.

Raipi C. Menapace, JR.

Edward A. Minler

JoN O. Newran

LAWRENCE NEWBSAN

MLARTIN OpPENHEIMTER

Otis P. Pearsall

Richard H. Pershan

Stephen J. Polzak

MIARUIN N. Rraor

BERNARD S. RoBdris

Norbert A. Scrilet

Rayarond Af. Shatribesg

WALter E. Shuttleworta

Jeanise Ritcrie Silues

ATONROE SILVERsCali

ROBERT J. Sisk

ARIEN Specter

Mfenvm Stan:

JorN T. SUbaK

Charles H. Vejuoda

Roger A. Wetcr

HowARD P. WILLE::S

George C. ZacrabY

MARIE MicMamon

Business Secretary

\section{CONTRIBUTORS TO THIS ISSUE}

Arthur Linton Corbin. B.A. 1894, University of Kansas; LL.B. 1899, LL.D. 1951, Yale University; LL.D. 1953, University of Chicago. William K. Townsend Professor of Law Emeritus, Yale Law School.

FrIedRICH Kessler. J.U.D. 1928, University of Berlin; Hon. M.A. 1947, Yale University. Professor of Law, Yale Law School. Member, Illinois Bar.

Roscoe T. Sterfen. A.B. 1916, College of Idaho; LL.B. 1920, Yale University. Professor of Law, University of Chicago Law School. Formerly Professor of Law, Yale Law School. Member, New York and United States Supreme Court Bars.

EpwIN W. BRIGGs. B.S. 1927, Oklahoma A. \& M. College; LL.B. 1932, University of Oklahoma; LL.M. 1935, Harvard University. Professor of Law, Montana State University School of Law. 